\title{
"Se puede conservar la cultura y también se puede aspirar": Language and Cultural Identities among the Cora of Mexico 1
}

\author{
Jacqueline López, William Frawley, and Joy Kreeft Peyton, Center for Applied Linguistics
}

\begin{abstract}
This paper examines the connection between heritage language and culture and the construction and maintenance of social and personal identities of the Cora, an indigenous people of the Mexican Sierra del Nayar, in Northwestern Mexico. Using the frameworks of the socially and linguistically mediated mind (Dennet, 1991; Harré \& Gillet, 1994; Searle, 1998) and the Continua of Biliteracy (Hornberger, 2002; Hornberger \& Wang, 2008), the paper presents data from interviews with Cora speakers to show how language and cultural connection support identity establishment and maintenance among the Cora. The data indicate that the Cora experience pressure to assimilate into mainstream Mexican society, yet they continue to manage multiple identities. One of the ways they do this is by shifting between an endogenous Cora identity and an integrated Mexican identity. The paper closes with recommendations on teaching Cora language and culture in school, so that their identities can be maintained and strengthened.
\end{abstract}

\section{Introduction}

The title of this paper, quoted from a Cora interviewee, expresses the paper's essence: minorities can preserve their identities and their heritage language and culture at the same time that they incorporate new cultural identities, but this preservation can be a challenge. The indigenous Cora people of Mexico seek to manage multiple identities while resisting pressures to assimilate. To do this, they draw on a combination of beliefs and activities that value, construct, and maintain their historical identity and multiple selves in social practice. In this paper we examine those beliefs and activities and present data from interviews with Cora speakers. We conclude by arguing that schools can play a role in the maintenance of heritage languages and cultures such as those of the Cora with curricula that support students' identities, while they also promote academic development.

\section{The Cora}

Of the approximately 24,390 indigenous Cora who live in Mexico (Jáuregui, 2004), most live in the Sierra Madre, which includes the states of Jalisco, Nayarit, and Durango. The Cora are heavily concentrated in the Nayarit mountain range of the Sierra del Nayar, located in northwestern Mexico. A growing Cora community also lives in Colorado and other parts of the United States. The Cora people and language are also known as Nayeeri, after the locale and a Cora hero, King Nayar. The Cora language is Southern Uto-Aztecan and one of Mexico's 68 national language groups, approximating a total of 364 languages (Instituto Nacional de Lenguas Indígenas, 2008).

The Mexican constitution safeguards indigenous languages and cultures as part of Mexico's cultural heritage "el patrimonio cultural" (Constitución Política de los Estados Unidos Mexicanos, 2008) and provides a linguistic rights framework that places indigenous languages 
and cultures on equal terms with the mainstream language and culture (Ley General de Derechos Lingüisticos de los Pueblos Indígenas, 2003). While the Cora community in La Mesa del Nayar speak Cora among themselves, they speak Spanish with their mestizo ${ }^{2}$ neighbors and sometimes among themselves as well. About $60 \%$ of the Cora are proficient in spoken Spanish (Summer Institute of Linguistics, 2008).

Cora customs blend agricultural, socio-political, and cosmological practices. The Cora are farmers and have their own internal hierarchical system of government alongside the Mexican municipal government. Cosmologically, the Cora have a pre-Hispanic, pre-Columbian, and preChristian naturalistic and polytheistic conception of the universe (Hinton, 1990; Jáuregui, 2004; Ramos, 1992). At the same time, they have incorporated Roman Catholic ceremonies into their rituals, "making their religious patrons, organization, and constant ceremonial activity . . . complex" (Hinton, 1990, pp. 46-47).

A major purpose of Cora religious and socio-political life is to ensure that their crops are healthy and abundant, and their calendar cycle is linked with maize cultivation (Magriña, 2002). The Cora system of government observes this cycle, which includes the ritual that Magriña (2002) calls "key" to the Cora identity (p. 25), the mitote ceremony. Mitote ceremonies occur six times a year, three times during the rainy season: mitote de la chicharra, sembra, y caza (petition for rain ritual), so that seed can grow; mitote del maíz tierno (tender corn), a celebration of the first crop in September; and mitote del esquite (dry corn), a celebration of the dry maize and beginning of a new growing cycle when the ritual seed is distributed. Three other mitotes occur during the dry season and correspond with the life cycle of individuals and society. These are the mitote del gobernador [governor's mitote], which reaffirms the civic-religious hierarchy of Cora social organization, velación y vejez [vigil and aging], which celebrates the last phase of growth of individuals, and mitote del los niños [children's mitote], which ensures the healthy growth of Cora children; and mitote del bautizo [mitote of baptism], which helps to ensure that Cora children grow up as Cora. ${ }^{3}$

The mitote is a family and community ceremony. Ritual charges or obligations include fasting, and sexual abstention, and several days of activity such as cooking, dancing, singing, praying, and blessing the maize (Jáuregui, 2004). An offering is made to Tatei Niwesika, the Cora's mother goddesses of the land, the moon, and the maize (CIESAS, 2004; Contreras, 1974, p. 57; Guzman, 2002, p. 130). Tatei Niwesika is considered a main deity who safeguards maize and ensures that it grows abundantly (Neurath, 2000).

The celebration of the mitote is unique to the Cora and continued after Spanish incursion into Cora lands. In fact, the Sierra del Nayar is the only region in Mexico that was not conquered by the Spanish in the 16th century (Nayarit Gobierno del Estado S.T., 2005). The Cora resisted Spanish influence by living in canyons and mountains at a distance from the Spanish and the growing mestizo community. When the Spanish did conquer the Cora in 1723, the Cora did not substitute their own beliefs with those of the conquerors. Instead they underwent "symbolic assimilation as well as cultural re-interpretation, which allowed the Cora to remain [autochthonous]" (Magriña, 2002, p. 235) and to continue practicing the mitote. Resistance 
against being conquered by the Spanish inspired the Cora to participate in Mexican independence efforts, and they joined the Mexican army and incorporated themselves as Mexicans, against the Spanish in the Mexican War of Independence. As Hinton (1990) explains, "They are Mexicans of Cora customs, and they remind others with pride of their long history and participation with the Mexican wars and their contribution to the War of Independence" (p. 48). With modernization, the Cora have been challenged as an indigenous group in Mexico and are now experiencing what Hornberger and Wang (2008, p. 4) call "sites of contestation," and they continue to strategize how best to undergo intense modernization, which includes the building of a highway from Tepic, the capital of Nayarit, to the hard to access Sierra. To examine how they respond to the pressures of assimilation, we turn to our theoretical framework.

\section{Heritage Language and the Mediation of Identity}

Aspects of identity can be understood through socio-cognitive frameworks. Dennett (1991), Harré and Gillet (1994), Searle (1998), and others have argued that the concepts of self and person are intelligible only insofar as they are seen as mediated by the symbolic practices of culture, especially language. Linguistic and other symbolic practices of a cultural group afford their users a perspective or viewpoint -- something roughly equivalent to what Whorf (1997) argued to be "habitual," practiced thinking (see also Bloch, 1998; Lantolf \& Thorne, 2006; Levinson \& Wilkins, 2006; Turner, 2002.) This argument suggests that we examine the role of language in the development, maintenance, and promulgation of personal identity by the Cora.

\section{In Speaking vs. By Speaking}

Broadly, language affords its speakers identity, or perspective, in at least two ways:

- Perspective generated by the language while one speaks, i.e., identity in speaking

- Identity generated because one is a speaker of the language generally, i.e., identity by speaking

We look at each in turn.

In speaking Cora. In speaking Cora, speakers use forms of the language that provide a way of thinking about and representing the world. Following the neo-Vygotskyan (Wertsch, 1985) and neo-Whorfian (Gumperz \& Levinson, 1996; Whorf, 1997) traditions, Frawley (1997) has shown that languages give their speakers linguistic means to develop a perspective and an approach to reality. Among these means are sentential particles, tense/aspect, modality, evidentiality, specificity, and other structures that represent the social world. For example, in English discourse, tense can be used make an epistemological statement about a speaker's degree of confidence in an assertion. Compare the two answers to the query below:

--Is Bob at home?

--He is. ("I was just there, and I have data that he is. You can rely on this.")

--He was. ("I was there and had knowledge of his being there, but I cannot guarantee that he is at home now.") 
The speaker uses grammatical patterns of English to express two perspectives. Using the present tense, the speaker presents himself as an assured knower; with the past tense, he presents himself as someone with incomplete information. In addition to the pattern shown in the example above, grammatical forms for representing perspective are used in self-directed speech during problem solving situations or to address other challenges. (See Frawley, 1992, 1997; Lantolf \& Thorne, 2006; Vygotsky, 1978; and Wertsch, 1985 for discussion.)

The Cora language also allows for the expression of perspective with grammatical categories. For example, Cora has three classes of ordered, pre-verbal particles to indicate speaker stance: a set of introducers, which mark subordination, questions, or doubt; particles, which signal subjecthood, evidentiality, sequentiality, and result; and the quotative, which indicates that the utterance's content originates from another speaker. We provide two examples here, from Casad (1984, pp.168 \& 169, 178). The first shows use of the dubitative particle (p. 169).

$$
\begin{array}{lll}
t^{y} i & p e-n^{y} \dot{u}^{\prime} u-k a & -m \dot{t}^{\prime} \dot{t}^{\prime} \\
\text { DUB } & \text { you-respond } & \text { HAB-DESID }
\end{array}
$$

"It seems as though you are angry."

The dubitative particle in pre-sentential position, $t^{y} i$, marks the speaker's tentativeness about the assertion, translated roughly as "it seems." This particle affords the speaker the means to signal a tentative approach to an assertion.

Below is an example of the quotative marker, signaling a source other than the speaker (Casad, 1984, p. 178).

$\begin{array}{lll}\text { tikin } & n^{y} e-t^{y} i-h i^{\prime} i-k^{w} i ' i & n^{y} a^{\prime} u \\ \text { QUOT } & \text { I-DISTR-NARR- } & \text { Well } \\ \text { INTR } & \text { be sick } & \\ & & \\ \text { "He said, 'I'm sick,' that's all.” } & \end{array}$

The reported speech above also includes a discourse particle of positive and finalizing commentary: "He said, 'I'm sick,' and, well, there you have it." This discourse particle connects the mind of the speaker with interlocutor belief; a hearer should not expect more from the speaker than what has already been said.

These examples illustrate that Cora's grammatical features allow speakers ways to mark perspective and stance. These features, used in the course of speaking Cora, contribute to the construction of Cora identity.

By speaking Cora. Now we consider the effects on identity of Cora speakers by speaking the language. As Hornberger and Wang (2008, p.13) note, by speaking a heritage language, "HLLs [heritage language learners] position themselves in social contexts, with specific reference to 
their choice of learning, or using either the L2 [second language] or the HL [heritage language]." Hornberger and Wang's observation, that by speaking a heritage language speakers define and situate themselves, is important to our work. We find that the Cora can present themselves as both Cora-speaking and Spanish-speaking selves. This pattern comes through readily in the interviews we report on below, as well as in ethnographic observations. According

to Hornberger and Wang (2008), language use can be understood along four continua:

1. Context, where heritage speakers' behavior in the heritage language ranges across local to global situations (micro to macro), is more or less oral or literate, and more or less bilingual/multilingual or monolingual.

2. Content, where speakers position themselves as more or less part of the minority or majority population, as vernacular or literary speakers, in linguistically contextualized or decontextualized situations.

3. Media, where speakers position themselves through language varieties, scripts, and communicative modes.

4. Development, where speakers range across receptive and productive abilities with use of their first or second language, orally or in writing.

A fully functioning bi/multilingual speaker can control use of the languages along both ends of all four continua. ${ }^{4}$ However, given the nature of heritage languages and their social and political contexts, many if not most heritage language speakers lack this control (Valdés, 2001).

Hornberger and Wang's model provides a framework for understanding the multiple proficiencies and identities available to heritage language speakers and, specifically, to the Cora. See also Friesner, 2007 and Makoni, Brutt-Griffler, and Mashiri (2007) for analogous studies in Zimbabwe and Quebec.) We find that the Cora have adopted multiple strategies for maintaining their linguistic and cultural identity, including beliefs about their language and culture, use of the language, and the practice of the mitote. Thus, in an ambiguous context where Mexican law protects and encourages indigenous language and identity maintenance, and at the same time mainstream Mexican society does not generally respect indigenous people as equals, the Cora of the Sierra del Nayar are favorably situated to maintain their language and culture over time as they push to live on par with the mestizo community. We now turn to the data and findings on the construction and maintenance of the Cora self.

\section{Methodology}

Over a three-month period, a co-author of this paper, Jacqueline López (JL) conducted ethnographic research and face-to-face interviews in Spanish (with the exception of one interview conducted in English) with 14 Cora language speakers and one heritage Spanish speaker in Nayarit, Mexico. $\frac{5}{5}$ The respondents, who answered 30 open-ended questions, were all bilingual in Cora and Spanish, except for the heritage Spanish speaker interviewed in English. (See Appendix for the interview protocol.) Interviews generally lasted between one and three hours. Six of the 15 interviewees were adults ranging in age from 47 to 65 ; seven were youth, ages 14 to 17; 2 were children, ages 9 to 12. Interviews were transcribed in Spanish. Segments included here are in Spanish and English. 
Interviews were supplemented with approximately three months of researcher observations in three largely Cora communities of Jesús María, Barrio de Guadalupe, and La Mesa del Nayar. Participant observations contributed to understanding of daily life experience as well as insight into statements made during interviews.

\section{Findings}

Our findings show that the Cora seek to maintain their language, culture, and identity within a context of language and cultural change. The Cora seek to strengthen their identity and maintain their heritage while also gaining access to agricultural, educational, and social growth, and are concerned about external forces, which threaten their language and culture.

Finding 1. Cora children, youth, and adults have developed strategies for maintaining and strengthening their language and cultural identities.

Strategies described by Cora interviewees include current and historical features that they hope will solidify their identity and preserve their language. In the interviews and observations we see that the Cora associate the following factors with Cora identity:

a. A sense of difference between the Cora and others, particularly mestizos or non-indigenous people based on distinct cultural, social, historical, and psychological world views.

b. Continued practice of the mitote, the sacred agricultural maize ritual, which reaffirms social and cultural understandings and expectations

c. A history of peonadas [worker groups] (organizations of peones, or unskilled day workers hired for agricultural work), a cultural feature of the past that some Cora would like to bring back.

One way the Cora seek to maintain their identity is to understand the differences between themselves and their non-Cora neighbors. A strategy for doing this is to let their Cora identity be known and to speak Cora in the Sierra community, among themselves and in the presence of Spanish speakers. This strategy is used by some Cora in an attempt to bring about a "Puro Cora" (pure Cora) community. For example, one interviewee, a traditional Cora leader, explained:

El Cora es el lenguaje que usamos aquí. [Mantengamos el lenguaje] para que no se pierda la cultura. Debemos aprenderlo todos. Hacer como los sacerdotes una doctrina donde te digan "Eres Cora: tienes que tener mentalidad que eres Cora y no lo pierdas y conserva lo tradicional." $\mathrm{Y}$ a la gente que viene de afuera hacerle saber que éste es un pueblo indígena... Que vayan conociendo cuáles son las costumbres que se deben respetar aquí. 
[Cora is the language that we use here. [Let's maintain the language] so that the culture does not get lost. We should all learn it. Do like the priests do - a doctrine where you get told: 'You are Cora: you have to have the mentality that you are Cora, don't lose it -- preserve the traditional. And let the people who come from the outside know that this is an indigenous town.... That they should start getting to know what customs should be respected here.]

One 15-year-old youth argued that only Cora should be spoken and heard. When JL asked her what strategies she suggested to preserve the Cora language and culture, she replied,

Pues enseñarles a nuestros hijos hablar Cora y decirles que cuando ellos tengan sus hijos que no les enseñen el español.

[Well, teaching our children to speak Cora and telling them that when they have their kids, to not teach them Spanish.]

Another respondent, an academic administrator, mentioned the importance of letting others know about the Cora language and culture while also maintaining them for oneself and the community.

Para brindar luz e informar a otros sobre la identidad y cultura Cora se necesita una nueva visión que verdaderamente sabe sobre la vida de los indígenas a través de una educación [donde el maestro esté capacitado culturalmente] y con ese enfoque de productividad. Se necesita un proceso de sensibilización, dando a conocer la importancia que tiene la cultura en sus diferentes formas...lo que beneficia identificarse o tener pertenencia hacia el grupo étnico y el grupo social.

[To spotlight and inform others about the identity and culture of the Cora there needs to be a new vision that genuinely knows about the life of the indigenous people through education [where the teacher is culturally capable] and with a focus on productivity. There needs to be a process of information dissemination, letting people know the value of the culture in its various forms... the benefits of identifying with and being part of the indigenous and social group.]

A community member in La Mesa explained that maintaining Cora identity can be done through bilingual and heritage language schooling in Cora and other languages:

Que se abran escuelas de la comunidad que sean intercultural bilingüe y que enseñen el Nayeeri y estructura de lenguajes indígenas como el Nayeeri para todos los niveles de educación, incluyendo la secundaria. 
[Let schools in the community be opened that are bilingual and intercultural and that teach Nayeeri and the structure of indigenous languages such as the Nayeeri for all levels of education, including in secondary school.]

One of the respondents, whose daughter took a leading role in the mitote ritual, representing a Malinche or a pure "virgin Mary-like symbol," claimed that the root of Cora identity is the mitote. Mitote participants take on different roles; an especially important role is the cook, which an individual typically takes on for five years. When JL asked how the mitote is preserved, an experienced mitote cook explained:

Pues, llevándolo. Yendo a realizar todo lo que se pide, todo lo que se celebra; todo lo que se hace ... pues para que no se pierda, para que siempre se preserve, se tiene que practicar. Las condiciones tienen que estar para que nosotros los Coras lo podamos seguir practicando.

[Well, keeping it up. Realizing all that is asked, all that is celebrated; all that is done ... . well, so that it does not get lost, so that it is always preserved, it has to be practiced. The conditions have to be there so that we the Cora can keep practicing it.]

The power of the mitote to affect identity extends beyond individual participation. While the foregoing Cora respondent explains the importance of participating in the mitote ritual, many Cora know the ritual in detail without having participated in it. That is, the tradition is passed on through oral language and stories. This transfer of knowledge is an example of what Bourdieu (1973) notes on communities maintaining their strength by "working together in a harmonious way to transmit cultural heritage" (p.73). For example, one respondent, when asked about his view of the mitote, explained:

Guardas un cierto respeto aunque no lo practiques. Por ejemplo, la mayoría de los Coras no están de acuerdo que en un acto social [en la televisión, por ejemplo] se desarrolle el mitote ... No es un juego. Lo practica un mayor . . . Entonces el mitote nomás es la práctica. No todos tienen el maíz sagrado. Se va transmitiendo por generación en generación.

You safeguard a certain respect [for the mitote], even if you don't practice it. For example, the majority of the Cora do not think that in a social act [on television, for example] the mitote should be carried out. It is not a game. An elder practices it. The mitote is thus the practice [of it]. Not everyone has the sacred maize. It gets transmitted generation by generation.

Finally, memory of the peonadas, although they no longer exist, forms part of Cora identity for some: 
La identidad no es nada más el lenguaje, es la forma de vivir, de actuar, de convivir, de tener sentido de solidaridad; de participación, de colaboración, de entrarle en ayuda mútua permanente. Por ejemplo nuestros abuelos trabajaban en común..... Ahorita ya no se ayudan y ya no hay las famosas peonadas.

[Identity is not just language, but it is also a way of living, of being, of sharing and having a sense of solidarity; of participation, collaboration, and entering a mutual assistance relationship. For example, our grandparents worked communally.... Today workers no longer help each other, and we no longer have the famous peonadas.]

Finding 2. In the midst of change, Cora identity can be preserved, and multiple identities can be empowering.

This finding speaks directly to the dynamic nature of identity, particularly in the categories of Context and Development in the Continua of Biliteracy model (Hornberger \& Wang, 2008), since they manifest a range of social activities, from micro to macro, and the relative bilingualism of the speakers. For the Cora, language and identity involve a complex interweaving that allows speakers an agile shift among equally active and available identities, given the context and pressures. Thus, multiple languages and identities are an advantage.

For example, in interviews, Cora respondents believe that their indigenous identity does not change as a function of being involved in progress. Three Cora respondents describe how they are able to manage their desire for social progress without losing their own identity:

La cultura no está peleada con el progreso o el desarrollo, puesto que se puede conservar la cultura y también se puede aspirar a tener una mejor calidad de vida. (Profesional de la Comisión Nacional para el Desarrollo de Los Pueblos Indígenas)

[Culture is not in combat with progress or development, since you can preserve your culture and also aspire to have a better quality of life.] (Professional working with the National Commission for the Development of Indigenous Communities (Commision Para El Desarollo, n.d.)

Yo aunque esté muy preparado, no la dejaría [la cultura]. No por el hecho de estar bien preparado voy a dejar mi cultura; yo sé que me sirve. (Profesor bilingue)

[Even if I am well prepared, I would not leave it [my culture]. Just because I am well prepared I am not going to leave my culture; I know it serves me.] (Bilingual teacher) 
Ellos [los mestizos] valen la cultura de ellos, ¿verdad? Entonces para que no vengan ellos y vayan [y digan] no te muevas y a dónde ir, nuestra cultura tiene que ser valorada también. Yo por eso siempre he participado en todas las dependencias porque a mí me gusta participar y luego por lo menos conocer cuál es la sistemática. (Líder de la comunidad y asistente de la educación)

[They [the mestizos, Mexican Spanish speakers] value their culture, right? So that the mestizos don't come here and tell us how to position ourselves and where to go, our culture has to be valued as well. That is why I have always participated in all agencies, because I like participating so that, at the very least, I get to know the system.] (Community leader and education assistant)

This third interviewee explains that he intends not only to maintain his Cora identity but also participate in the dominant Mexican society. He also thinks that it is important for the Cora culture to have the same status as the mestizo culture; towards this he participates in all organizations and their activities.

When respondents were asked how the Mexican government or other entities can help the community preserve their language and traditions, two answered that indigenous communities can progress by cultivating their lands while also preserving the Cora tradition:

Pues, principalmente necesitamos gente que venga y nos enseñe como se puede cultivar [mejor] las tierras... que es lo que podemos cosechar aquí, que es lo que nos puede

ayudar aquí a mejorar. Aparte de que nos hagan entender que es necesario para que conservemos nuestra tradición, nuestro lenguaje.

[Well, principally we need people to come and teach us how we can [better] cultivate our lands... what can we grow here, what can help us improve, in addition to helping us understand what is necessary to conserve our tradition, our language.]

[Necesitamos] pedir apoyo para que el gobierno apoye en la gobernación de cada festival y haya mayor inversión a la cuestión educativa. No se le ha dado el apoyo suficiente, como inversión económica, capacitazión, profesionalización. [También es importante] aceptar a los estudiantes indígenas a la UPN [Universidad Pedagógica Nacional]. [Se necesita] el apoyo productivo agricultural considerando la costumbre de los Coras.

[We need to ask for support from the government so that they can support each festival and so there can be greater investment in education. [Education] has not been given sufficient support, such as economic investment, capacity 
building, professionalization. It is also important to accept indigenous students in the UPN [National Pedagogical University, which supports teachers and those in the teaching and education fields]. We need support for productive agricultural activity, considering the customs of the Coras.]

The foregoing shows that some respondents are seeking to maintain Cora identity and traditional norms while also managing multiple identities, progressing, and becoming empowered. Within the Context continuum, micro and oral features are on one end and are less powerful, and macro and literate features are on the other end and are more powerful. While the Cora have been concentrated within the micro and oral areas, they are making headway into the macro and the literate dimensions. The Cora understand that they do not have to forget or let go of their culture in order to "progress," but rather maintain their identity and also become productive members of modern society. Some also realize the importance of receiving greater support from the government, such as financial resources and professional development.

These productive tensions can be seen in respondents who report that they will maintain their Cora-specific self-view and their ability to communicate and live in the current society. The following respondent shows that he values both the language and culture of his parents and the language and culture of his mestizo neighbors.

Realmente nos damos a conocer y nos valoramos como seres humanos, como indígenas y no nos avergonzamos. Por ejemplo, yo no me avergüenzo de ser indígena. No me da pena con nadie. Para mí es un gran valor el tener una cultura, el ser diferente en cuanto a la cultura de los demás, así por decirlo, de nuestros vecinos mestizos, y podernos comunicarnos con nuestros semejantes que hablamos el mismo lenguaje [los mestizos] y también poder hacer las ceremonias que hacían mis padres.

[We understand ourselves and we value ourselves as human beings, as indigenous people, and we are not ashamed. For example, I am not ashamed to be indigenous. I am not embarrassed about it with anybody. For me it is of great value to have a culture, to be different from others, to say it that way, for example from our mestizo neighbors, and be able to communicate with our equals who speak the same language [the mestizos] and also be able perform the ceremonies that my parents used to do.]

Finding 3. External factors play a role both in reaffirming internal Cora identities and threatening traditional ways of life.

The threats to Cora traditions include geographical change and change of domicile, such as the emigration of Cora speakers and community members from regions of Mexico to the United States. For example, a governor of the Cora region explains that the Cora recent migration from Jesús María, Mexico, to Colorado and other areas of the United States is problematic for Cora maintenance and identity in the Sierra. He explains: 
Les da por irse a otras tierras, como por ejemplo [se van] a los Estados Unidos, y ellos ya casi no vienen por acá. Ya no les interesa llevar a cabo los cargos tradicionales, ya no les interesa pertenecer al grupo que lleva a cabo todavía sus costumbres.... Nuestras costumbres son nuestras, no traídas de otra parte.

[Cora] leave to go to the United States, and they almost never come back here. They no longer want to fulfill traditional roles, nor belong to a group that still carries out its customs....our customs are ours and are not brought from another place.]

For some, Cora identity seems to have a fixed association with the physical locale in the Sierra. Many interviewees expressed the belief that Cora migrants may die if they do not come back to the Sierra and celebrate the mitote and other customs. Interviewees also mentioned the power of God to make Cora members sick if they stop practicing traditional ways. The interviewees' responses give the impression that Cora identity is formed in ongoing tension between internal and external forces. Some interviewees also expressed the view that the Cora can preserve their culture and identity with the resources they currently have, by reaffirming their rituals, even if abstractly, using the perspective of themselves as outsiders and in-group solidifiers.

In March 2006, construction began on a highway from Tepic, the capitol city of Nayarit, to the Sierra. This construction has had the impact of increasing the interaction between indigenous communities, including the Cora, and mestizo communities. When asked whether they think the construction of the highway will advance or diminish Cora identity, 1/3 of the respondents said that Cora identity would not be diminished, slightly more than $1 / 3$ said that it would be, and the rest gave vague answers or did not respond to the question. A Cora traditional community leader argued that the highway will eventually weaken Cora identity:

Pues yo creo que sí [va reducir la carretera la identidad Cora] porque mientras se acerquen gente que venga de afuera, los imigrantes, pues si, va a ir acabando cada día más.

[Well I think that yes [the highway is going to reduce the Cora identity], because while people get close that come from the outside, the immigrants, well yes, Cora identity is going to reduce each day more and more.]

A traditional leader believes it beneficial to exclude mestizos from the Cora community because they are not aware of the Cora's sacred places:

Porque ya mucho de los niños que están creciendo ahorita actualmente, aunque sean Cora el 100\%, como que les da pena, vergüenza de ser Coras... Pues a veces ayuda mucho no aceptar gente de afuera debido que la gente que viene de afuera no sabe ni qúe es lo que hace uno. Tenemos lugares sagrados donde 
la gente quiere hacer algo ahí y nosotros no lo permitimos, porque para nosotros son lugares sagrados.

[Because many kids that are growing up now, even if they are Cora $100 \%$, it's as if they are embarrassed, ashamed to be Coras.... Well, sometimes it helps a lot that we don't accept people from the outside, since they do not know what it is that we do. We have sacred places where people want to do something, and we do not permit it because for us, they are sacred places.] (Traditional Cora leader)

Coras also experience discrimination from other groups, which is evident in the response of an interviewee who works in the higher echelons of education in Mexico and yet has confronted negative attitudes about his language and culture. This respondent, an education administrator, shares his life experiences and explains the importance of maintaining and practicing one's language and culture:

Adaptándose a ese nuevo ambiente sin dejar de hablar la propia lengua es un proceso de adaptación, transición dífícil. Tenemos que acostumbrarnos a ese nuevo ambiente sin perder la lengua que se tiene. Desde este momento se está adaptando de manera natural, por inercia se tiene que ir uno adaptando. Tuvimos que sufrir agresión. Tamborazos, "indio piojoso"... Eso no me hizo perder mi identidad. Reconozco lo que soy, y me sirvió para emerger y hacer una casa igual que ellos. Voy a trasladarme igual y hacerlo como ellos. Proceso de transición me llevó fuera de mi cultura porque no más terminé sin practicarlo. [Es importante] seguir practicando el lenguaje y las costumbres hasta donde se puede. El lenguaje no es algo ceremonial.

[We adapt to this new environment without losing our own language. It is a process of adaptation and a difficult transition. We have to get used to the new environment without losing the language that we have. From that moment on, we are adapting it in a natural manner through [inertia]. We had to suffer aggression and hard hits, such as being called 'lice headed Indian...' That did not make me lose my identity. I recognize who I am, and it served me to emerge and build a house that is the same as their house. I will remake myself equally and do it like them. A transitional process took me out of my culture, because I did not practice it. It is important to keep practicing the language and the traditional way of doing things as much as possible. Language is not something that is ceremonial.]

This respondent describes his experience of discrimination:

El mestizo no nos respeta. Ellos se creen superiores. La misma gente que vive aquí y ha convivido mucho tiempo, creen ser superiores a nosotros...Han compartido la vida en sociedad con los Coras, pero no lo han. 
[Mestizos do not respect us. They believe they are superior. The same people who live here and have shared with us for very long time, think they are superior to us... They have shared life in society with Coras, but they have not.]

These examples suggest that some Cora do not trust mestizos, whom they perceive as a possible threat to the familiar ways of life in the community, even when the Cora are the majority.

In some cases, when teachers do not respect students' language and culture and focus only on Spanish language proficiency, schooling also threatens Cora life. A traditional leader explains:

Principalmente los alumnos que están en la escuela son los que ya no quieren ser Cora aquí [en Jesús María] porque es donde hay maestros mestizos en la primaria de aquí y los maestros regañan a los niños porque están hablando en Cora; y lo hacen porque no los entienden, entonces ahí el niño esta aprendiendo a identificarse mejor con las palabras en español."

[Principally students who are in school are the ones that no longer want to be Cora here [in Jesús María], because it is where there are elementary school mestizo teachers, and the teachers yell at the children because they are speaking in Cora; and they do it because they don't understand them, and so here the child is learning to better identify with words in Spanish.]

One teacher interviewed said that his job as a teacher is to assimilate the indigenous students in their community so that they "forget their roots." His approach to his work seems to confirm one parent's opinion that teachers were not interested in their students' culture.

Some respondents argued for the need of bilingual schooling, which community members and leaders also believed an ideal way to negotiate external pressures by reaffirming Cora identities. A traditional leader who was once the municipal governor explained:

Debe de ser que Anahuac (la única escuela primaria en la comunidad Jesús María) sea bilingüe; de otro modo es que estamos perdiendo mucho el dialecto.

[Anahuac (the only elementary school in Jesús María) should be bilingual; otherwise we are losing much of the dialect.]

\section{Conclusion}

In this paper we have shown that the Cora seek to maintain their identity, and may shift among multiple identities, in a complicated context of personal, cultural, and sociopolitical pressures. These identities can provide a strong resource, allowing the Cora linguistic richness and reaffirming their indigenous selves and multiple perspectives. The Cora draw on cultural features and strategies such as a reliance on classical rituals (e.g., the mitote) that strengthen their 
indigenous identity and allow them to maintain a productive tension between who they are historically and who they are pressured to be.

We close with a discussion of Cora language and culture education in Mexican schools and how it can be strengthened. Some elementary school children in Cora communities receive bilingual schooling in government-sponsored schools that provide Cora language textbooks. In addition, at the insistence of parents and the community, Cora language and indigenous culture are taught in at least one high school in La Mesa del Nayar in the Sierra. This indigenous high school incorporates Cora language, identity, and culture in its instruction. ${ }^{6}$ However, the only elementary school in Jesús María is a monolingual Spanish-medium school with primarily mestizo teachers. Moreover, even if students attend a bilingual elementary school and later the indigenous high school, students experience a break in Cora instruction during middle school, which offers instruction only in Spanish. During school-based observations, JL observed that schools lack culturally relevant instruction and resources and provide limited support for teachers in providing content knowledge in the Cora language. Fully articulated and supported bilingual and bicultural schools, from elementary school through high school, would allow students to build a transnational identity, where they could function competently both in Cora or another indigenous language, and in Spanish.

Despite these obstacles, schools are being built and others are being planned in the Sierra, with a vision to maintain and enrich the heritage language of the Cora and the indigenous community. For example, in 2008 an indigenous university was opened in La Mesa that was founded on cultivating respect and empowerment for indigenous communities. A Cora academic administrator whom JL interviewed explained that he wanted to build heritage language schools that would foment a respect for autonomy and traditions. Since the mitote has an affirming power as a virtual identity marker for the Cora, this administrator would like to introduce this ritual into the school curriculum and use books that cover the subject. However, this proposal would need to be considered carefully, because the mitote has strict rules about participation, and some Cora individuals exclude themselves or others because they believe that they are not "sufficiently prepared" to be a part of it. However, if it were possible and appropriate, the mitote and other identity markers (such as the history of the peonadas) might be included in the school curriculum to support students' identities.

The Cora educational experience is similar to that espoused by Posnick-Goodwin (2005) and others who argue for the establishment and support of American Indian Education Centers and other identity enrichment centers. They cite research showing that meaningful engagement with content through indigenous and ancestral knowledge can enhance Native American and Chicano students' academic performance, because "their heritage and their viewpoints [are] represented in the school curriculum" (Posnick-Goodwin, 2005, p. 18).

Godina (2003), Fishman (2001), and others argue that culturally relevant instruction situated in ancestral history must ultimately be tied to heritage language instruction, since it is a "marker of identity" (Fishman, 2001, p. 5). Efforts to facilitate student achievement by highlighting and valuing students' languages and cultures can be seen in efforts by indigenous communities in the 
United States, such as the Hupa, Karuk, and Yurok curriculum used in the Klamath-Trinity Joint Unified School District in Hoopa, California). Indigenous students from this district whose teachers used the Hupa, Karuk, and Yurok curriculum claimed that this culturally relevant curriculum has allowed them to find their voices (Newberry, 2008).

In this regard, the only respondent in this study who was born in the United States and who identifies with the Cora culture, but considers herself a Chicana and does not speak Cora, reported that she was able to learn mathematics and science in the Sierra indigenous high school in La Mesa del Nayar better than in her Oregon public high school, because teachers in the Sierra indigenous high school respected both her mestizo and indigenous cultures, used specific strategies that allowed her to learn math and science better in the Sierra, and she learned about the Cora language, while in the United States no connection was made to the culture she came from or the languages she speaks. As Hornberger (1990) explains, groups can "connect and transfer strategies across languages" (p.227) and at the same time preserve their identities and voices.

Hornberger and Wang (2008) suggest that more attention and agency be granted to "bringing heritage forward" (p. 15) and to encouraging heritage language speakers, such as Native Americans in the United States and the Cora in Mexico, to "position their own expertise" (p. 24). They argue for "greater curricular attention to minority, vernacular, and contextualized whole language texts in academic contexts" (p. 16) and argue that "assisting HLLs to advance their language expertise requires understanding what these learners can do with, instead of what they do not know about, the HL" (p. 26).

Indeed, facilitating the academic development of indigenous language learners such as the Cora, and allowing them to manage their identities as they choose and as we see the Cora doing in this study, requires that we value the resources and strategies that they bring to the social and educational context. Mainstream society in Mexico, including educational programs in Mexico, should recognize the Cora's rich cultural and linguistic inheritance, and join the Mexican government in its call for the preservation and enrichment of indigenous identity and the incorporation of indigenous voices as an authentic part of the national culture.

\section{References}

Bourdieu, P. (1973). Cultural reproduction and social reproduction. In R. K. Brown (Ed.), Knowledge, education, and cultural change: Papers in the sociology of education (pp. 71112). Durham, UK: Taylor \& Francis.

Bloch, M. (1998). How we think they think. Boulder, CO: Westview.

Casad, E. (1984). Outline of Cora grammar. In R. Langacker (Ed.), Studies in Uto-Aztecan grammar, IV (pp.151-489). Dallas: Summer Institute of Linguistics.

CIESAS (2004). Identidad - Coras de Nayarit [Identity - the Coras of Nayarit.] Retrieved from http://pacificosur.ciesas.edu.mx/perfilindigena/coras/opcion04.html 
Commision Para El Desarollo de los Pueblos Indigenas [National Commission for the Development of Indigenous Peoples]. (n.d.). Juárez, México. Retrieved from http://www.cdi.gob.mx

Contreras, G. S. (1974). Los Coras y El Rey Nayarit [The Coras and King Nayarit.] S.A. de C.V. Nayarit Mexico: Compostela.

Constitución Política de los Estados Unidos Mexicanos, reforma 29-07-2010. (2010). Diario Oficial de la Federación del 5 de febrero de 1917 [Political Constitution of the United Mexican States, reform 07-29-2010. (2010). Oficial Federation Diary, February 5, 1917.] Retrieved from http://www.cddhcu.gob.mx/LeyesBiblio/pdf/1.pdf

Dennett, D. (1991). Consciousness explained. New York: Little Brown.

Fishman, J. (2001). Can threatened languages be saved? NY: Multilingual Matters.

Frawley, W. (1992). Linguistic semantics. Hillsdale: Erlbaum.

Frawley, W. (1997). Vygotsky and cognitive science. Cambridge: Harvard University Press.

Friesner, M. (2007). Language policy and multiple transnational identity: The case of Russian immigrants in Montreal. Working Papers in Educational Linguistics, 22, 25-44.

Godina, H. (2003). Mesocentrism and students of Mexican background: A community intervention for culturally relevant instruction. Journal of Latinos and Education, 2, 141-157.

Guzman, A. (2002). Mitote y el universo Cora [Mitote and the Cora universe]. Guadalajara, Mexico, D.F.: Conaculta-INAH/Universidad de Guadalajara.

Gumperz, J., \& Levinson, S. (1996). Rethinking linguistic relativity. Cambridge: Cambridge University Press.

Harré, R., \& Gillet, G. (1994). The discursive mind. Thousand Oaks, CA: Sage.

Hinton, B. T. (1990). Coras, Huicholes, and Tepehuane. S.A. de C.V. Mexico DF: Instituto Nacional Indigenista.

Hornberger, N. H. (2002). Multilingual language policies and the continua of biliteracy: An ecological approach. Language Policy, 1, 27-51.

Hornberger N. H., \& Wang, S. C. (2008). Who are our heritage language learners? Identity and biliteracy in heritage language education in the United States. In D.M. Brinton, O. Kagan, \& S. Bauckus. (Eds.), Heritage language education: A new field emerging (pp. 3-35). New York: Routledge.

Instituto Nacional de Lenguas Indígenas (INALI, 2008) Nuestra riqueza lingüística [Our linguistic richness]. Retrieved from http://www.inali.gob.mx

Jáuregui, J. (2004). Coras, Pueblos indígenas de México contemporáneo [Coras, indigenous people of contemporary Mexico]. S.A. de C.V. México DF: Comisión Nacional para el desarollo de los pueblos indigenista. Retrieved from http://www.cdi.gob.mx/index.php? option $=$ com docman $\&$ task $=$ doc details $\&$ Itemid $=\&$ gid $=13$

Lantolf, J., \& Thorne, S. (2006). Sociocultural theory and the genesis of second language development. Oxford: Oxford University Press.

Levinson, S., \& Wilkins, D. (Eds.) (2006). Grammars of space. Cambridge: Cambridge University Press.

Ley General de Derechos Lingüisticos de los Pueblos Indígenas [The law on the linguistic rights of indigenous peoples]. (2003). Secretaria general del H. Congreso de la Unión. Retrieved from http://www.diputados.gob.mx/LeyesBiblio/pdf/257.pdf 
Magriña, L. (2002). Los Cora entre 1531 y 1722 [The Cora between 1531 and 1722]. S.A. de C.V. Mexico, DF: Instituto Nacional de Antropología e Historia, Universidad de Guadalajara.

Makoni, S., Brutt-Griffler, J., \& Mashiri, P. (2007). The use of "indigenous" and urban vernaculars in Zimbabwe. Language in Society, 36, 25-50.

Nayarit Gobierno del Estado S.T. (2005). Historia, tradiciones y costumbres del grupo étnico Cora [The history, traditions, and costumes of the Cora ethnic group]. México: Tepic Nayarit.

Neurath, J. (Spring, 2000). Ritual and historical territoriality of the Nayari and Wixarika peoples. Journal of the Southwest, 42(1), pp. 81-110.

Newberry, D. (March 21, 2008) Rescuing languages from extinction. Jefferson Public Radio, Oregon. Retrieved from http://www.ijpr.org/Feature.asp?FeatureID=836

Posnick-Goodwin, S. (2005). Healing the wounds: Can schools win back the trust of Native Americans? California Educator, 10(4), 6-19. Retrieved from http://archive.cta.org/CaliforniaEducator/v10i4/Feature 1.htm

Ramos, G. G. (1992). Los Coras. [The Cora]. Dirección general de publicadores del Consejo Nacional para la Cultura de Artes S.A. de C.V. Mexico D.F: Instituto Nacional Indigenista.

Searle, J. (1998). Mind, language, and society. NY: Basic Books.

Summer Institute of Linguistics. (2008). Ethnologue. Retrieved from http://www.ethnologue.com/show language.asp?code $=\mathrm{crn}$

Turner, S. (2002). Brains/practices/relativism: Social theory after cognitive science. Chicago: University of Chicago.

Valdés, G. (2001). Heritage language students: Profiles and possibilities. In J. K. Peyton, S. McGinnis, \& D. Ranard, (Eds.), Heritage languages in America: Preserving a national resource. (pp. 37-77). Washington, DC: Center for Applied Linguistics.

Vygotsky, L. (1978). Mind, language, and society. Cambridge: Harvard University Press.

Wertsch, J. (1985). Vygotsky and the social formation of mind. Cambridge: Harvard University Press.

Whorf, B. L. (1997). Language, thought, and reality. Cambridge: MIT Press. 


\section{Appendix. Interview Protocol}

¿Cuál es su nombre completo?

¿Cuántos años tienes?

¿Dónde vives y desde cuándo?

Opción: ¿Cuál es su trabajo / su labor / su responsabilidad en la sociedad Cora?

¿Eres Cora? Si_No_, ¿eres Huichol__Tepehuano__Mexicanero__ Mestizo__Chicano_?

\section{Aprendiendo el lenguaje patrimonial Cora}

¿Hablas Cora? Si lo hablas, ¿empezaste a adquirir el lenguaje desde que tuviste uso de razón?

¿La recuperación y la preservación del lenguaje y de la cultura Cora son esenciales? ¿Por qué?

¿Es fundamental que su lenguaje se pueda escribir? ¿Si la respuesta es sí, qué se necesita para poder lograr que todos los niños Coras lo escriban?

¿Qué estrategias sugiere para preservar el lenguaje y la cultura Cora con los recursos que tienen?

¿Usted siente que su lenguaje y cultura corren peligro de ser extinguidos o cree que su lenguaje siempre sobrevivirá?

¿Cómo han combatido actividades o actitudes negativas sobre su lenguaje? Es decir, ¿Cómo se han resistido y cómo se han adaptado?

La rica lengua y cultura Cora es evidente y se conserva a base de canciones, poemas, oraciones, leyes, saludos etc. ¿Sabe usted canciones, oraciones y leyendas? ¿Podría compartir o decirnos el nombre de unas?

¿Específicamente, se sabe cantos rituales o narraciones Coras sobre el mitote? ¿Sobre el Rey Nayar (todavía lo honoran y le brindan ofrendas) etc.?

¿Qué cuentos o leyendas le cuentan a sus/los niños?

\section{Construcción de Identidad}

¿Cómo el lenguaje y la cultura Cora es parte de su identidad?

¿Qué la/lo identifica como Cora? ¿Qué te hace saber que tu cultura es algo del cual estas orgullo/a de?

¿Cuál es su actitud sobre el mitote? ¿Es decir, en que formas participas u otros participan en el mitote y porque? (Por ejemplo, ¿tienes o tenías un cargo en el mitote?) 
¿Cómo se mantiene/progresa el mitote? ¿Es parte de tu identidad?

¿La tierra en la que vives y los recursos naturales son parte su identidad?

¿Qué condiciones aquí en la sierra ayudan a la preservación del lenguaje, la cultura y la construcción de la identidad Cora?

En la sociedad Cora, ¿la identidad se ve en la defensa del territorio, de la comunidad y de la estructura colectiva?

¿Cómo piensa usted que se puede desarrollar con identidad Cora?

Es decir, dicen unos que la construcción de la carretera va a reducir la cultura y la identidad Cora, ¿es verdad? Cómo se puede prevenir esto?

¿Qué sugieres para brindar luz e informar a otros sobre la identidad y la cultura Cora?

¿Cómo mejoraría su identidad?

\section{Cultura}

Explícame si tienes una filosofía Cora (ley de vida, ideas de como se comporta un Cora)

¿Qué es lo que más desea para sus hijos o para los niños Cora?

¿Hábleme sobre “el costumbre”? ¿Cómo se preserva?

¿Sabe hacer alguna artesanía? ¿O algunos de tu familia hacen artesanías?

Específicamente, si quiere, explique de la etapa antes de la conquista en 1723. ¿Cómo era diferente al tipo de vida que se vive hoy? ¿O es similar?

¿A lo que yo he leído, el Rey Nayarit era y sigue siendo muy grande en su cultura;

¿todavía le dan tributo? ¿A quién le dan tributo?

¿Cómo podemos los Coras, otros grupos étnicos, Mestizos interesados, Chicanos (Mexicanos nacidos en los E.U. y con política progresista que valora a los indígenas) y demás promover la rica cultura Cora?

\section{Conexiones, Necesidades, Aportaciones al Mundo Exterior}


¿Qué tu piensas que es importante decirles a los que originan de la Sierra y que tienen sangre indígena, sobre la lengua, cultura, y costumbres Coras (u de otras etnias indígenas)? Es decir ¿qué ayudaría a concienciar y brindar sensibilización a la sociedad con raíces indígenas?

¿La identidad y cultura Cora de la Sierra es parte de la identidad y cultura indígena en el resto de México y en los Estados Unidos?

¿Necesitan mas ayuda? ¿Cómo le podría ayudar a usted el gobierno Mexicano para que les aporte mas ayuda? Explica ejemplos específicos por favor.

¿Saben si otros indígenas de México, de los Estados Unidos son similares a la de ustedes?

¿Qué más le gustaría añadir sobre su lengua, cultura, o identidad que todavía no hemos abarcado?

\section{Interview Protocol (English Translation)}

What is your full name?

How old are you?

Where do you live and since when?

Optional: Where do you work/What is your responsibility in Cora society?

Are you Cora? Yes___ No___ Are you Huichol___ Tepeuano

Mexicanero___Mestizo___ Chicano_?

\section{Learning about the Cora Heritage Language}

Do you speak Cora? If you do, did you acquire the language when you were a child?

Are the recuperation and the preservation of the Cora language essential? Why?

Is it fundamental that your language can be written? If the answer is yes, what is needed in order for all children to be able to write it?

What strategies do you suggest to preserve your language and culture with the resources that you have?

Do you feel that your language and culture are in danger of being extinguished or do you think your language will always survive?

How have you combated negative attitudes or activities about your language? That is, how have you resisted and how have you adapted? 
The rich Cora language and culture are evident and conserved through songs, poems, prayers, laws, greetings etc. Do you know songs, prayers and legends? Can you share these or tell us the names of some? Specifically, do you know ritual songs or narrations about the mitote and or about King Nayar (do you still honor him and bring him offerings?)

What stories or legends do you tell your children or children in general?

\section{Construction of Identity}

How are language and culture part of your identity?

What identifies you as Cora? What makes you proud of your culture?

What is your attitude about the mitote? That is, in what ways do you or others participate in the mitote and why? (For example, did you have or do you currently have a traditional role in the mitote?)

How is the mitote maintained and how does it progress? Is it part of your identity?

The land that you live in and natural resources are part of your identity?

What conditions here in the Sierra help the preservation of the language, culture, and construction of Cora identity?

In Cora society, is identity reflected in the defense of territory, of the community and the collective structure?

How do you think that development can occur as Cora identity is maintained?

That is, some say that the construction of the freeway is going to reduce Cora identity. Is this true? How can this be prevented?

What do you suggest to bring light and information others about the Cora identity and culture?

How can your identity be improved?

\section{Culture}

Please let me know if you have a Cora philosophy (law of life, ideas about how a Cora should act).

What is it that you most desire for your kids or for Cora kids?

Talk to me about "el costumbre." How is it preserved?

Do you know how to do folk art? Or do family members know how to make folk art? 
Specifically, if you want, explain the time before the conquest in 1723 . How was it different from the type of life that you live today? Or is it similar?

From what I have read, King Nayar remains a great figure in your culture. Do you still pay tribute to him? Or who do you pay tribute to?

What can Coras, other ethnic groups, interested Mestizos, Chicanos and others to do promote the rich Cora culture?

\section{Connections, Needs, and Contributions to the Exterior World.}

What do you think is important to tell those who originate from the Sierra and have indigenous blood about the language, culture and customs of the Cora (or other indigenous groups). That is, what would help create consciousness and bring sensibility to indigenous societies?

Is the Cora identity of the Sierra part of the indigenous identity and culture in the rest of Mexico and in the United States?

Do you need more assistance? How can the Mexican government help so that you are given more assistance? Please explain with specific examples.

Do you know if other indigenous groups in Mexico and in the United States are similar to yours?

What else would you like you include about your language, culture and identity that we have not yet talked about? 


\section{Notes}

1. "You can conserve your culture and also aspire." This statement was made by a Cora respondent.

2. Mestizo refers to the mainstream Mexican citizens who are of mixed Spanish and indigenous ancestry.

3. For detailed information on the mitote, such as the calendar cycle, see Magriña (2002).

4. Similar observations are made by Fishman (2001), whose principles for Reversing Language Shift (RLS) provide a theoretical framework and an agenda of practical social action for successful development of the heritage language. Fishman developed an eight-stage continuum of disruptions to a language's existence -- the Graded Intergenerational Disruption Scale (GIDS) - which takes into account various contexts for language use, from the local and home to public and established venues.

5. The single English-language interviewee chose to be interviewed in English. We recognize that for the best measures of self and language, these interviews could have been conducted in Cora, thus revealing the Cora self in speaking the language. However, the interviewer, JL, does not speak Cora, although she is fluent in Spanish, as are the Cora interviewees.

6. This school also offers culture-specific instruction for the Wixárika or Huicholes, the second largest indigenous group in the Sierra del Nayar after the Cora, and the Tepehuanos and Mexicaneros, who also live in La Sierra del Nayar. 